\section{Evolution of European Union's policy towards the Mediterranean region}

\author{
Anna Diawol \\ Andrzej Frycz Modrzewski Krakow University (AFMKU) \\ Faculty of International Relations \\ annadiawol@tlen.pl
}

\section{SUMMARY}

This paper examines some specific problem in Euro Mediterranean relation. Author decided to concentrate on two main issues: the characteristics of the institutions of the Union for the Mediterranean, indicating similarities and differences in the Euro-Mediterranean programs and the presentation of specific new initiatives. The author will also summarize the main possible positions in the ongoing debates about the need to reform the European Union addressed to the countries of North Africa and the Middle East.

Keywords: Mediterranean region, European Union, North Africa, Middle East

\section{INTRODUCTION}

Postponed and cautious response of the European Union to the protests in Tunisia and Egypt suggests that it was surprised by the development of the situation. Only after a few days, the high representative of foreign policy, Catherine Ashton, gave a speech in which very generally stressed that the principles of democracy, human rights are a very important matters for the Union, thus suggesting to the leaders of Tunisia and Egypt, that EU will not tolerate the use of forces against the civilian population. With the development of the situation, one could notice the change rhetoric of the EU response to the increasingly tense situation in North Africa, hitherto allies like Ben Ali and Mubarak were summoned to hear the voice of the people and resign from their positions. Support of the citizens of Tunisia and Egypt was not a simple matter for the Union, because it meant admitting to previous wrong assumptions of Euro-Mediterranean policy: closer cooperation with undemocratic regimes, supporting the status quo in the region, in exchange for economic cooperation in the fight against terrorism and cooperation on immigration policy.

The history of Euro-Mediterranean relations goes back to the $60 \mathrm{~s}$, namely the creation of the European Community. Early 90's brought a concretization of the policy of the European Union aimed at developing cooperation with the Mediterranean region, its main framework was presented in 1995 at a conference in Barcelona. Euro-Mediterranean Partnership setting out the basis for interregional cooperation for 9 years, was the main forum where problems of the region were being discussed. In 2004 European Neighborhood Policy was founded, by establishing a basis for action plans of bilateral cooperation. Since 2008 the new initiative The Union for Mediterranean is being implemented.
Hence, the subject of this study is the problem of Euro-Mediterranean relations with a particular focus on the Union for Mediterranean. Its launch rises a few basic questions. First, consider the reasons for its existence where there are already two institutions under which dialogue is conducted. Secondly, what the Union for Mediterranean can add to the already existing framework of cooperation. It is also important how the European Union changing its Euro-Mediterranean policies. Drawing lessons from past mistakes wants to make euro-mediterranean policy more real, often abandoning the assumptions made in 1995. Despite the difficulties arising from the news topic and its complexity, the author decided to concentrate on two main issues: the characteristics of the institutions of the Union for the Mediterranean, indicating similarities and differences in the EuroMediterranean programs and the presentation of specific new initiatives. The author will also clashed briefly summarize the main possible positions in the ongoing debates about the need to reform the European Union addressed to the countries of North Africa and the Middle East. The paper was written based on the literature, the choice of texts has been selected to reflect the specifics of this article. In the alternative, the author also used newspaper articles.

\section{EURO - MEDITERRANEAN INITIATIVE}

Euro-Mediterranean Partnership was launched at the 1995 Conference in Barcelona. The conference concluded with the adoption of the Barcelona Declaration, which is a document setting out the basic goals and directions of cooperation. The idea was to create an instrument of the Union, giving the opportunity to develop a mutual area of peace, stability and prosperity, ensuring sustainable economic and social development and mutual understanding.

Declaration launched three types of partnership: political and security, economic and on cultural and social affairs. During the conference politicians agreed that the cooperation will take place on two planes: bilateral association agreements signed by EU and Mediterranean countries and in the meetings of foreign ministers from countries participating in the process, also at the meetings of ministers dealing with specific areas, officials, experts and parliamentarians (Anderson, 2005).

Euro-Mediterranean Partnership has been exposed to many trials and difficulties. Firstly, the international situation has negatively affected the implementation of the provisions of the Barcelona Declaration. Secondly, the Union itself, which 
through the involvement and a good example would work to accelerate the reform and change, was often busy with its own affairs and problems, in preparation for the next expansion. For lack of reform, are also responsible Arab states that have not won on the conduct of reforms set in the declaration. We can see their apparent lack of interest, since the partnership, according to them was not really offer, which were waiting because they see that it is ineffective in fighting real problems of the region.

Process failures arise from its structure, based on the same terms and conditions of cooperation for all countries. Years of experience has shown that there is no common interest and priorities of participating countries in the process. Misconception was the assumption that the priority for countries of North Africa and the Middle East is the democratization, liberalization and the rule of law. During anniversary conference in 2005 the European Commission confirmed in its statement that the results of the assumptions adopted in Barcelona are far from expectations.

Although there are many positive achievements, much remains to be done in order to fully realize the potential of the Barcelona Declaration (Conclusions for the VIIth Euro-Mediterranean Conference, 2005, p.1).

The reform of the Euro-Mediterranean cooperation has been carried out in 2004, building a collective security system under Euro-Mediterranean Partnership, has been complemented by the bilateral dimension of the European Neighbourhood Policy, which responds only to those who carry out appropriate reforms, and its instruments are individually tailored to the needs and requirements of partners. The concept of bilateral cooperation in the EPS gave possibility to note the specific problems of the country and pursue policies suited to their abilities. The positive effect can be observed in Morocco, which has taken a dialogue with the European Union and systematically carried out the activities established in action plan. Program stability of the region by focusing on bilateral relations, was also questioned, since this policy could to create even greater divisions in the Mediterranean region. One country has complied obligations, the rest remained behind. Ensuring security in the Old World need to engage, in the process of democratization, all countries of the ENP. The nature of contemporary problems as migration, should not be consider only from the viewpoint of bilateral relations (Aliboni, 2010).

\section{THE UNION FOR MEDITERRANEAN - FOUNDATION FOR MULTILATERAL COOPERATION}

The year 2008 was a time of great debate on the Mediterranean, a place it occupies in EU policy, the complexity of the problems of previous initiatives and the challenges ahead. The criticism with which they met the Euro-Mediterranean Partnership and European Neighbourhood Policy, allowed to believe that the concept of Union for Mediterranean is an attempt to rescue Euro-Mediterranean relations and is like the "lifebuoy" for earlier initiatives.

UfM was established at the initiative of French President Nicolas Sarkozy. On its formation the following factors had influence: the growing marginalization of the Mediterranean countries in the international arena, ENP not to carrying out its functions - and the desire to restore the dominance of France in the Middle East and North Africa. Initially, presented his idea at a conference in Toulon, February 7, 2007. President Sarkozy, wanted to strengthen relations only between countries with access to the Mediterranean Sea. So the only part of the EU member states would take active participation in the new project. Half a year later, the new version of the project presented the Spanish Foreign Minister, Miguel Maratinos. Euro-Mediterranean Union would have grouped all the countries of the EU and Mediterranean countries, and cooperation within its framework would focus primarily on socio-economic integration. At the end of December 2007, France with Spain and Italy, during the meeting in Rome, issued a Call of Rome, which called for preserving the original idea of President Sarkozy, with the possibility of inclusion in the work of other members of the Union. Such a solution could not be accepted by Germany. A compromise was reached at a meeting of President Sarkozy and German Chancellor Angela Merkel in Hanover. The agreement assumed by the creation of the Union for the Mediterranean, bringing together the region's countries and all EU members, and the inclusion of the European Commission in the preparatory work indicated that initiative will has Community nature. The final version of the project is called the Barcelona Process: Union for the Mediterranean, was officially inaugurated at a summit in Paris on 13th July 2008. Earlier, the European Council in March and the European Commission in May, prepared appropriate recommendations (Borkowski, 2009).

The original intention of the President of France has been significantly revised, its scope, the proposed structure and objectives. Union for the Mediterranean was to be loosely associated with the EU bodies and its structure should promote economic cooperation. Structure was based on the mechanisms modeled on the G-8. As a result of intervention of European Union members - traditionally interested in developing cooperation with its eastern neighbours the initiative has been synchronized with existing Euro-Mediterranean programs. Trying economic integration most concerned EU countries in cooperation with Mediterranean region, has been strengthened by political component, that gives influence to the process, all EU members. The Europeanization of the initiative was affected by Germany. This country could not agree on the existence of the entity, funded by the EU budget, but without its real impact on decision-making (Aliboni, 2009).

As for the attitude of Arab states to a new initiative, a critical assessment have expressed by 
Libya and Syria who do not accept Israel's participation in the project. Turkey feared that UfM could mean the end of its accession negotiations and was intended as an alternative to its EU membership. Israel has expressed opposition to its contribution to the League of Arab States, which eventually became an observer in UfM. A positive response could be observed in the Balkan countries who were satisfied with their inclusion in the Euro-Mediterranean initiative (Driss, 2009).

The final realization of the project of the Union for the Mediterranean took place in October 2008 at a conference in Marseilles, where it was found that:

The Barcelona Process: Union for the Mediterranean aims to promote mutual understanding and the importance of the Mediterranean for Europe, stressed the importance of mutual ties, deep cultural and historical associations and the need for rapid response to common strategic challenges. These challenges need to be re-considered and cooperation should be passed on to the next level (Join Declaration of the Paris Summit, 2008, p. 8).

Before the adoption of an official document in July, the Commission reviewed the achievements of the Barcelona Process, stressed its importance and contribution in shaping the policy of dialogue, peace, stability and the fact that since 1995 the meeting of the Partnership were the only forum in which the Mediterranean countries (Illustration 1.) had the opportunity to exchange opinion, provide constructive dialogue and the promotion of a strong commitment to stability and democracy. The Commission also pointed out shortcomings and difficulties, which occur during the implementation of the Partnership, and the fact that its contribution to resolving long-running conflict in the Middle East was not sufficient (Emerson, 2008).

\section{Illustration 1.: Members of the Union for Mediterranean}

The Union for the Mediterranean

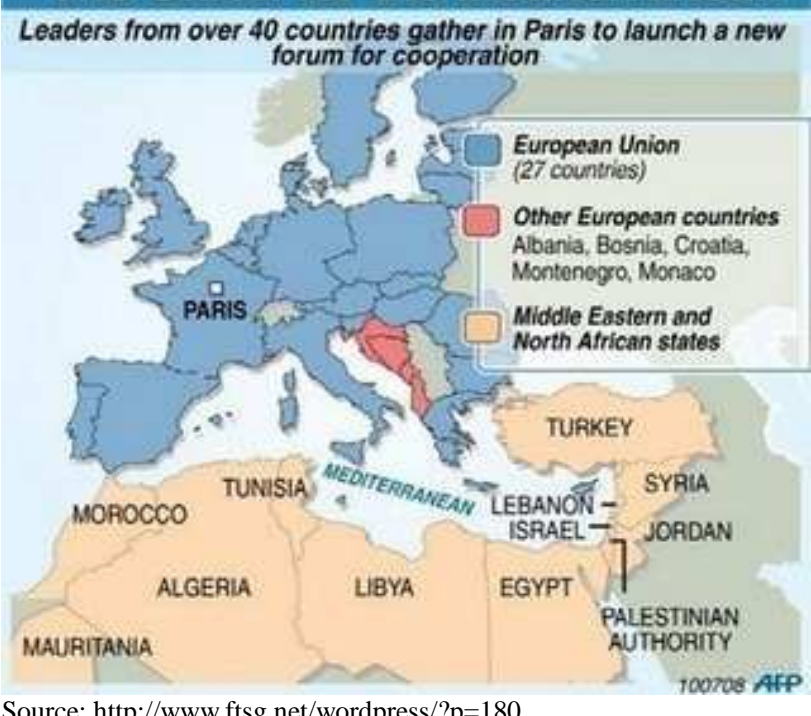

It was emphasized that the purpose of this new initiative is to strengthen multilateral relations, increase co-responsibility of all countries for the process. Union for the Mediterranean based on the existing structures of the Barcelona Process and bilateral relations within the ENP framework. The initiative is multilateral and is based on regional and transnational projects, should move regional integration and cohesion, to a higher level. It covers all European Union countries, members of the Barcelona Process and its observers and the European coastal states such as Croatia, Bosnia and Herzegovina, Montenegro and Monaco (Wojna, 2009).

Upgrading of relations will be effected by summits of Heads of Government which should take place every two year, taking a two-year work program and a number of concrete regional projects. Meetings of foreign ministers take place between the summits. Joint ownership is based on the establishment of a co-presidency One is designated by the Union and the other by the Mediterranean countries. Better institutional management is ensured by setting up of a joint committee based in Brussels, is composed of representatives of all countries participating in the initiative. Its role is primarily involved in the preparation of meetings of Heads of State and Government, in emergency situations requiring rapid response should become a consultative forum between Euro-Mediterranean partners (Balfour, 2009).

Another new institution is the Joint Secretariat. It was equipped with legal personality and statutes. Its functions are: forge contacts with all institutions of the Union for the Mediterranean, the preparation of concrete projects and seek funding for their implementation. The head of the institution is Secretary General elected for 3-5 years. He can be from the Middle East and North Africa countries or from the European countries. The role of the parliamentary dimension in UfM was emphasized by the inclusion the Euro Mediterranean Parliamentary Assembly in the work (Balfour, 2009).

Development of cooperation is also based on establishing new multilateral programs. In 2008 at a summit in Paris foreign ministers meeting in Marseille, approved six projects:

- -De-pollution of the Mediterranean implementation of 2020.

- -Maritime and land highways - upgrading of existing routes and to create a coastal highway,

- -Euro Mediterranean Solar Plan - the development of alternative energy.

- -Civil Protection Programme - aimed to prevent natural disasters.

- -Establishment of the Mediterranean University in Slovenia - the scientific cooperation of the North and South.

- -The initiative for the development of entrepreneurship - helping small and medium enterprises. 
As for the financing of the Union for the Mediterranean, it has to be done through already existing programs and, in addition founds can come from the proceeds of the private sector, contributions from partner countries and international financial institutions, regional banks and other measures resulting from bilateral co-operation of member states of UfM (Suel, 2008).

\section{THE FIRST PROBLEMS}

Establishment of the Union for the Mediterranean is the result of a compromise between the governments of North and South countries. Its founding was not without an echo among the opponents, the leader of Libya, Colonel Qaddafi, called the new initiative as back to colonialism and refused to cooperate. The first period of its operation, rather multiplies the questions about the future of Euro-Mediterranean relations than dispels them. As a results of political situation in the Mediterranean region (escalating conflict between Israel and Palestine), that at the request of Egypt, who was the first of the Mediterranean countries held copresidency, all conversations and meetings under UfM structure were suspended in late 2008. For a whole year of 2009, it was not known how, Union and implementation of projects would look like.

The impasse in euro mediterranean relations as result of conflict in the Gaza Strip showed that regardless of the nature of the initiative in the Middle East, it will always be closely dependent on the Israeli-Palestinian conflict. It should be noted that none of the Euro-Mediterranean initiative does not have instruments that may influence events in Gaza, however indirectly, by promoting a favorable climate for talks aimed at contributing to stability and security in the region.

Egypt's decision undermined the credibility of UfM and mutual trust in the region. Instead of suspending work on building the institutions UfM Egypt could find a way to combat the crisis by using intergovernmental nature of the initiative. It is true that Egypt has taken a lot of diplomatic efforts to end the conflict, but his first reaction showed that UfM may be the next hostage to Middle Eastern crises .

Joint Secretariat, based in Barcelona, was officially appointed 4 March 2010, the SecretaryGeneral Ahmed Masadeh is from Jordan and he was elected in January 2010, which is why the EU could have finally start its activities (Suel, 2008).

\section{THE IDENTITY OF THE UNION FOR MEDITERRANEAN}

To understand the significance of the changes introduced by the Union for the Mediterranean in the Euro-Mediterranean relations, the basic issues and political identity should be considered and examined as well as UfM relationship with the ENP, its institutions and achievements.

In Euro Mediterranean Partnership Arab countries were the guests in EU institutions, but within UfM they are its co-owners and therefore UfM is more vulnerable to external factors as demonstrated by the crisis in Gaza. On the other hand, Mediterranean countries may treat it as a chance to show his point of view, in the Partnership and the ENP could only respond specific proposals from the EU, while in the UfM may initiate some activities. Intergovernmental nature of UfM could be useful to resolve conflict situations. Egypt's reaction showed, however, that it became the opposite. UfM begins to operate two years after its launch in an atmosphere of mistrust and anxiety, but also of hope (Suel, 2008).

Not entirely clarified is the issue of succession of the acquis developed under the Partnership. The EU will be continue initiating economic programs, build a free trade zone in the Mediterranean. This can be a basis for cooperation between the European Commission and the institutions of the UfM. What's more is not excluded that the Commission will engage in the implementation of large projects under UfM. Most of controversy and confusion are on a matter of social and humanitarian issues. They occupy an important place in the achievements of the Partnership, which developed platform for open dialogue and has formed a number of networks and linkages between North and South. The inclusion of social and civil level to UfM is not convenient for EU countries. Joint ownership of the institution as outlined by one of the main architects of the Union for the Mediterranean Henri Guiana lies primarily in the fact that the Arab countries are empowered to say definitely not to European proposal and force their point of view, in such fundamental issues as human rights, the EU will be reluctant to tolerated compromise. This case should be as soon as possible clarified in the future intergovernmental meetings (Driss, 2009).

Joint Presidency aims to introduce a balance between the EU and partners from the North Africa and Middle East, share responsibility for the process and emphasis equality in relations. This idea, however, does not seem real. The EU has the resources and tools that has developed over the years, in order to pursue a common foreign policy, so speaking with one voice is not much of a problem. On the other side are profoundly different countries, with no internal mechanisms of joint cooperation, caring more about their own interests than entire region.

Lack of precision as to the competence of political bodies within UfM and its relationship with existing initiatives may result that Mediterranean countries will not want to make efforts for unspecified political profits. Some countries are satisfactory with their bilateral relations within the ENP. It seems that Morocco is more interested in implementation of action plans under ENP than political structure within UfM, also Tunisia and Algeria are seeking to develop bilateral economic cooperation with the European Union. Algeria wants to become a direct supplier of energy for the European market, Tunisia has begun discussions on enhancing trade. UfM raise many question, but the 
most important is what it can offer for Mediterranean countries. UfM has specific tasks to perform, the implementation of multilateral projects announced in Paris, and should focus on their implementation, without undue illusion that it can support the political solidarity towards North Africa and Middle East (Aliboni, 2009).

Initiative of political integration, expected at the beginning of cooperation, is hardly realistic, the Union for the Mediterranean is rather a union of projects, than unity union. Mediterranean countries accept work on specific projects, which are agreed on very fast as creation of Euro Mediterranean University, or Solar Plan, development of small and medium enterprises. This idea focuses on areas where possibility of strengthening cooperation, have already noted. Specific initiatives and concrete measures are more appropriate in the Euro-Mediterranean relations than political statements. Focusing on cooperation in economic and financial dimension does not necessarily mean the collapse of the approach took in 1995 at the Barcelona Summit. Prosperity and economic development can become a force for change, without forcing and making the conditions as is within ENP. The original idea of the political integration was rejected by the Mediterranean countries, who say yes for union projects but do not agree with political union. Multilateral cooperation is an attempt to adapt the Barcelona Process to the real situation of the region. The final verdict and assessment will have to wait, but much depends on whether the political aspirations of the EU towards the Mediterranean region will be toned down and it will be provide pragmatic policy. Mediterranean countries need to understand that economic cooperation is not the main priority, it is only one of many stages. The EU's objective is to create peace, stability and security towards Euro-Mediterranean region (Aliboni, 2010).

\section{CONCLUSION}

The events of early 2011 in North Africa provide new challenges for the leaders of the European Union and new problems to solve - the need to review the existing euro mediterranean Initiatives. Since the beginning of February, the European Commission Announced an Increase of EU funds for Humanitarian aid and for migration programmes. In early March, the Union presented its new proposal addressed to the North African Partnership for democracy and shared prosperity. The document was presented jointly by the High Representative and Catherine Ashton, European Commission President Jose Manuel Barroso. Initially, was endorsed by Member States at an extraordinary session of the European Council. It is pointed out the need for qualitative change in EU policy towards the South neighborhood - primarily through the application of the Principles of differentiation and conditionality, and assumes that partnerships will be based on three pillars. Firstly, the EU should concentrate on issues of human rights, constitutional reforms and justice, fight against corruption and on activities in support for democratic change. Secondly, should support the building of civil society, develop and direct dialogue with the Inhabitants of particular regions. Thirdly, the sector of small and medium-sized enterprises should receive a higher level of support, paying particular attention to education, health and the development of poorer regions. This document has been criticized by some member states of the European Union. UK and Germany are calling for more stringent conditions for determining the co-operation, opting for a wellknown so-called - carrot and stick policy. However, southern neighbors as Italy, Malta want to continue the good-neighborly relations, based primarily on economic cooperation. Another controversial issue at the council meeting was the discussion on migration policy towards the Mediterranean region. While Commission President Jose Manuel Barroso stressed the need for "solidarity and fair sharing of Responsibility" in dealing with migration, German Chancellor Angela Merkel had Referred to "existing instruments," and noted that the future of young people lies in their native countries. After a closer examination of the document, it's hard not to notice that the Union has not presented a new offer to the North Africa countries, almost everything has already been indicated in the Barcelona Declaration, Paris, or in the The New Wider Europe Neighbourhood Policy. One can only hope that this proposal will soon be expanded with concrete action plans for the coming years and European Union will substantiate the new distribution of funds.

Changing its Policy in the Arab countries, the European Union should not do it due to altruistic reasons but mainly because of its own interest in stability and prosperity of North Africa. This requires more than short term actions and is necessary for turning again to the Barcelona Declaration's aims. In a consistent and courageous manner the EU should undertake actions in order to change and reorganize its policy. Choosing the Islam option in Tunisia, Egypt and Morocco is the main challenge that will appear in the nearest future. The hidden fears of Islamic threat have come alive again after the enthusiasm for Arab uprisings. Europe needs to undertake effort to change its perception of Mediterranean for better understanding of social problems together with respecting democratic values and human rights. As an example, in order to encourage North Africa's new governments to cooperate, EU can broaden the trade potentials of agrarian goods. Implement less restrictive visa regulations in the field of migration and facilitate access to education and trainings. EU should be using programs that support economic growth, education, initiatives aimed Young people and women. In the field of political reforms, EU can offer support in preparations for free election for example sending observers to the elections. It can also provide expert consultations Nongovernmental organizations can give trainings and courses for political parties and the candidates. EU has vast experience in fighting 
corruption and can conduct advisory missions. However EU should also coordinate the resources transferred to the countries of North Africa and cooperates with other countries and organizations regarding this matter. It is necessary to update plans in the scope of European Neighbor Policy in way so that they are adjusted to current changes and New challenges. More extensive expert support from the Union in the process of change is worth considering, for Europe has here great experience due to the history of such member countries as Poland, Czech Republic, Hungary or Slovakia. Next to bilateral dialogue, multilateral cooperation in the scope of democracy and building civic society should be extended, the Union from its side should implement here facilitations in the flow of people. Subsequent matter is the balance between the east and west neighbor policy mainly in the scope of finance and flexibility in transferring aid not as up till now according to 7-year financial perspective but according to needs and given country's development. Next matter is establishing the relations between the representatives of Islamic movements, for they will have bigger political role especially in Egypt and Tunisia.

Situation in the Arab world is diversified is specific countries. What can be useful in Tunisia, not necessarily has to fit in Egypt or Algeria. On one hand the EU can act bilaterally according to country's specific needs, on the other hand it has to think in a general way for many of the present challenges have regional nature.

Multilateral cooperation in the Mediterranean region should therefore be renewed. Here one can see a chance for the Union for the Mediterranean, which so far has struggled with many political and institutional problems. In January, the current Secretary General has resigned his position. He has justified his decision saying that he was beginning his work in a totally different situation, and without member countries' involvement he is not able to carry on working on his own. New secretary, coming from Morocco, was called in July 2011. The FrenchEgyptian presidency in Union for Mediterranean is still in power till today, even though in the beginning it was meant to be changed after two years, e.i. in 2010, according to the rotation principle. Despite the rough beginnings, Union for Mediterranean creates possibility of the enhanced regional cooperation. But this requires political support from EU for Maghreb and Mashriq countries and rethinking its competencies. Union for Mediterranean in its current form and without political support is not an appropriate instrument for promoting cooperation between Europe and North Africa in the Mediterranean region.

\section{REFERENCES}

Aliboni, R. (February 2010): Security and cooperation on security in current Euro Mediterranean relations (In:10 Papers for Barcelona 2010, ISS)

Alibon, R.-Ammor, F. M. (January 2010): Under the Shadow of Barcelona; From the EMP to the Union for the Mediterranean, (In: EuroMesCo Paper 77)

Anderson, K. (April 2005): The Euro Mediterranean Partnership (County Administration of Västerbotten)

Barcelona Process: Union for the Mediterranean, European Commission COM (2008) 319, 20 May 2008.

Baulfor, R. (March 2009): The Transformation of the Union for the Mediterranean (In: Mediterranean Policy, vol. 14, issue 1)

Borkowski, P. J., (2009): Europejska Polityka Sasiedztwa (Difin,Warsow)

Conclusions for the VIIth Euro-Mediterranean Conference of Ministers of Foreign Affairs, Luxemburg 31 May 2005, p. 1 (In:

http://europa.eu/rapid/pressReleasesAction.do?reference=PRE S/05/134\&format=DOC\&aged=1 \&language $=E N \&$ guiLangua ge=en)

Driss, A. (2009): Southern Perceptions about the Union for the Mediterranean (In: New EU Member States Positions regarding the Union for the Mediterranean, Institute of Public Affairs)

Emerson, M. (March 2009): Making Sense of Sarkozy's Union for the Mediterranean (In: CEPS Policy Brief, no. 155)
Escribano, G. (2008): The Mediterranean Union: A Union in Search of a Project (In: Working Paper, Real Instituto Elcano, no. 13)

Join Declaration of the Paris Summit for the Mediterranean, Paris 13 July 2008, p. 8 (In:

http://www.parlamento.it/documenti/repository/affari\%20euro pei/APEM/dicIstitutivaUpM2008.pdf)

Marseille, Final Statement, 3-4 November 2008, (In: http://www.parlamento.it/documenti/repository/affari\%20euro pei/APEM/dicFinaleMarsigliaUfM.pdf)

Parzymies, S. (2009):, Bezpieczeństwo i wspótpraca $w$ regionie Morza Śródziemnego - wielkie wyzwanie dla Europy, (In: Stosunki Międzynarodowe, no 3-4)

Putting the Mediterranean Union in Perspective (June 2008): (In: EuroMesCo Paper 68)

Statutes of the Secretariat of the Union for Mediterranean, 2010 (In:

http://www.europarl.europa.eu/meetdocs/2009_2014/documen ts/empa/dv/final_version_u/final_version_ufm.pdf)

Suel, A. (Winter 2008): From the Euro-Mediterranean Partnership to the Union for the Mediterranean (In: Perception http://www.sam.gov.tr/perceptions/volume13/winter/asli_suel. pdf)

Wojna, B. (2009): Trudne poczqtki Unii dla Śródziemnomorza (In: Sprawy Międzynarodowe, no. 1) 